\title{
Napawanie w regeneracji kokili do odlewania ciśnieniowego aluminium
}

\author{
Surfacing in the aluminum die-casting \\ metal mould regeneration
}

\section{Streszczenie}

Opisano zużyte przez zmęczenie cieplne oraz uszkodzone mechanicznie segmenty kokili napawane metodą TIG. Przedstawiono analize metod stosowanych w regeneracji stali narzędziowej do pracy na gorąco. Badano wpływ technologii napawania na właściwości warstw z dwóch wybranych spoiw. Określono warunki napawania i obróbki mechanicznej napawanych elementów form wtryskowych do odlewania ciśnieniowego części ze stopów aluminium.

\section{Wstęp}

Zaletą odlewniczych form metalowych zwanych kokilami jest możliwość ich wielokrotnego użycia. Ich wysoka trwałość sprzyja zachowaniu powtarzalnej dokładności wymiarowej odlewu, jego małej chropowatości powierzchni, możliwości pozostawienia małych naddatków na obróbkę ubytkową itp. Szczególnie nadają się do zautomatyzowanych procesów odlewania prowadzonych z dużą wydajnością i są szeroko stosowane w masowej produkcji części ze stopów lekkich np. dla przemysłu motoryzacyjnego. Na formy metalowe stosuje się stale narzędziowe do pracy na gorąco.

Temperatura zalewania ciekłego stopu aluminium do kokili zawiera się w granicach $650 \div 850^{\circ} \mathrm{C}$. Czas pozostawania odlewu w kokili wynosi od $6 \div 10$ s dla odlewów małych do kilku minut dla odlewów dużych.

Podczas pracy kokile ulegają naturalnemu procesowi zużycia wskutek zmęczenia cieplnego oraz oddziaływania ciekłego metalu, jak również doznają lokalnych mechanicznych uszkodzeń. Wytwarzanie nowych form jest na ogół procesem drogim i technologicznie skomplikowanym, zarówno ze względu na złożony kształt

Dr inż. Piotr Białucki, dr inż. Wiesław Derlukiewicz - Politechnika Wrocławska.

\section{Abstract}

Worn by thermal fatigue and mechanically damaged segments of the permanent molds, were hard surfaced by the TIG welding method. The analysis of methods applied in the regeneration of tool steel for hot work was introduced. The influence of technology on the properties of surfacing layers of two selected filler metals was presented. Conditions for surfacing and machining regenerated elements of injection molds for die- casting of aluminum alloy were specified. formy, jak i na proces obróbki cieplnej użytej na nie stali. $Z$ tego względu ważne znaczenie ma regeneracja zużytych form m.in. przez napawanie, zwłaszcza wtedy, kiedy ubytki materiału są nieduże i wystarczą napoiny niewielkiej grubości.

Regeneracja formy staje się łatwiejsza, kiedy kokila o złożonym kształcie nie jest monolityczna, lecz składana. Formy odlewnicze do trudnych odlewów mają skomplikowaną budowę i składają się z obudowy oraz wkładek formujących odlew, rdzeni, wypychaczy itp. Części składowe kokili mają różne właściwości mechaniczne i mogą być wykonane z innych materiałów, różnią się też intensywnością i wielkością zużycia. Wówczas do regeneracji można zastosować różne materiały do napawania, zależnie od tego, jaką spełniają funkcję. Przykładem takiej formy odlewniczej jest kokila do odlewania korpusów zacisków hamulcowych, którą omówiono w tym artykule.

\section{Zastosowane materiały}

\section{Materiał podstawowy}

Obiektem badań była kokila do odlewania samochodowych zacisków hamulcowych, wykonana ze stali WCL wg PN-/H85021:1986 (X37CrMoV5-1 wg PN EN 
ISO 4957:2002, 1.2343 wg DIN). Zawartość pierwiastków stopowych w stali przedstawiono w tablicy I.

Jest to stal narzędziowa chromowo-molibdenowa stosowana na narzędzia do pracy na gorąco. Wykonuje się z niej głównie formy do odlewania pod ciśnieniem stopów cynku, magnezu i aluminium, a także wkładki matrycowe, nożyce i gilotyny do cięcia na gorąco, elementy pras i form do tłoczenia metali lekkich, wkładki do formowania tworzyw sztucznych itp. Cechą stali WCL jest mała wrażliwość na gwałtowne zmiany temperatury, a przez to mała skłonność do powstawania powierzchniowej siatki pęknięć. Wytrzymuje silne nagrzewanie się powierzchni roboczej spowodowane np. stosunkowo długim kontaktem z obrabianym materiałem. Ma też bardzo dużą hartowność, jest odporna na odpuszczanie i zachowuje wytrzymałość w wysokiej temperaturze [1]. Cenną właściwością stali WCL jest mały wpływ obróbki cieplnej na zmianę wymiarów obrabianej części (ok. 0,02\%), co pozwala wykonywać z niej części na gotowo przed obróbką cieplną. Dobra podatność na polerowanie ma korzystny wpływ na dokładność przylegania części w formie oraz na efekt estetyczny wyrobu.

Podobnie jak inne stale narzędziowe do pracy na gorąco, również stal WCL należy do materiałów o bardzo ograniczonej spawalności i tylko w wyjątkowych przypadkach, takich jak naprawy narzędzia, może zachodzić konieczność połączenia jej z innymi gatunkami stali. Procesy spawalnicze związane z napawaniem regeneracyjnym zużytych narzędzi ewentualnie napoiny o specjalnych właściwościach mogą być zastosowane również do produkcji narzędzi nowych.

Technologia napawania form odlewniczych ze stali narzędziowej do pracy na gorąco musi uwzględniać warunki pracy napoin w wysokiej temperaturze, aby ich trwałość nie była mniejsza od materiału podstawowego. Dobre właściwości do pracy w takich warunkach stale narzędziowe uzyskują dzięki odpowiedniej obróbce cieplnej (rys. 1), ale ciepło procesu spawania zmienia te właściwości. Dlatego narzędzia po napawaniu poddaje się najczęściej ponownej obróbce cieplnej, aby otrzymać pierwotne właściwości.

$Z$ tego względu najbardziej odpowiednim spoiwem jest takie, które ma podobny skład chemiczny jak materiał podstawowy, aby obróbka cieplna po napawaniu była właściwa dla obu materiałów - napoiny i materiału podstawowego. Niektórzy producenci opracowują spoiwa do konkretnego gatunku stali, np. elektroda EWNL przeznaczona jest do napawania stali WNL, elektroda EWC4 do stali WC4, czy też EWWN1, dla której warunki ulepszania cieplnego napoin odpowiadają warunkom ulepszania stali WWV [3]. Według klasyfikacji spoiw do napawania zgodnie $z$ normą DIN 8555 do napawania stali narzędziowej do pracy na gorąco przeznaczone są materiały spawalnicze $z$ grupy trzeciej oraz szóstej [4].

Taki sposób podejścia do zagadnienia napawania jest istotny wtedy, kiedy od narzędzia wymaga się stabilności struktury materiału i dużej wytrzymałości w wysokiej temperaturze pracy.

Jeżeli jednak warunki pracy narzędzia z takich stali są łagodniejsze lub nie całe narzędzie jest jednakowo obciążone, stosowane są uproszczone sposoby regeneracji napawaniem, ograniczające się do podgrzewania wstępnego i wyżarzania po napawaniu, np. wg schematu przedstawionego na rysunku 2. Wówczas napoina będzie miała inne właściwości niż napawana stal.

Wyboru metody napawania, rodzaju spoiwa, sposobu przygotowania części do napawania, zabiegów cieplnych przed i po napawaniu należy dokonać, biorąc pod uwagę gatunek napawanej stali, gatunek użytego spoiwa, warunki pracy narzędzia, a także wielkość i kształt napoiny oraz jej położenie $w$ formie odlewniczej.

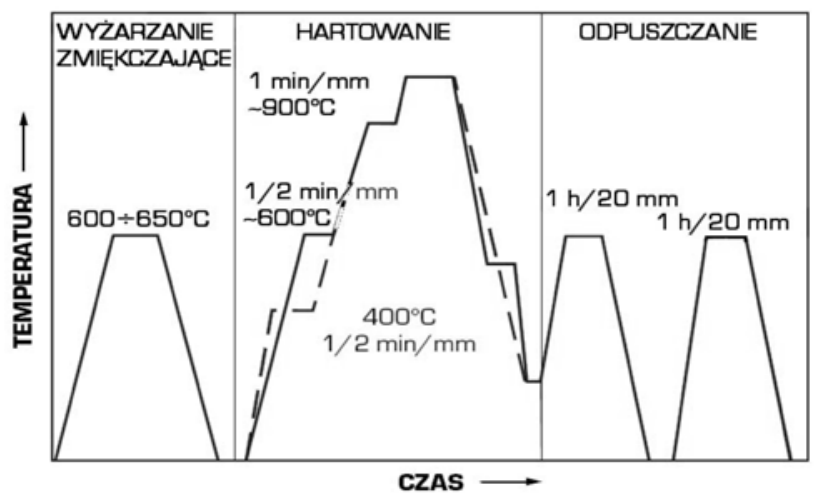

Rys. 1. Obróbka cieplna stali narzędziowych do pracy na gorąco [2] Fig. 1. Heat treatment of tool steel for use in the increased temperature [2]

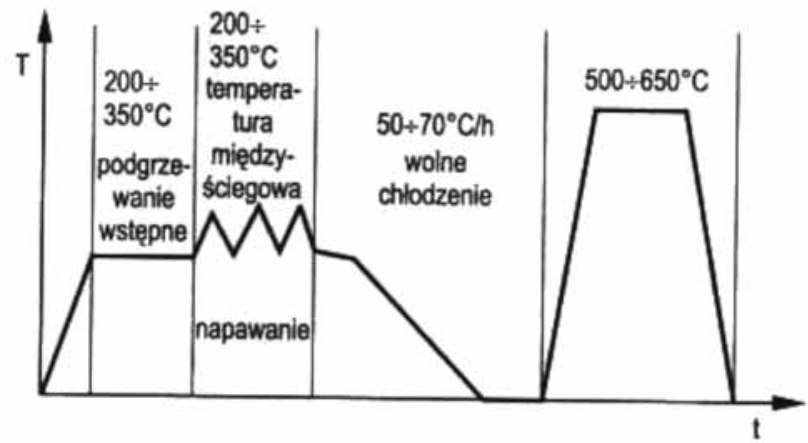

Rys. 2. Zabiegi cieplne przed i po napawaniu [4]

Fig. 2. Heat treatment before and after surfacing by welding [4]

Tablica I. Skład chemiczny stali WCL wg PN-/H85021:1986

Table I. Chemical composition of WCL steel acc. to PN-/H85021:1986

\begin{tabular}{|c|c|c|c|c|c|c|c|c|c|c|c|c|}
\hline \multirow{2}{*}{ Stal } & \multicolumn{12}{|c|}{ Pierwiastki stopowe, \% } \\
\hline & $C$ & $\mathrm{Mn}$ & $\mathrm{Si}$ & $P$ & $S$ & $\mathrm{Cr}$ & $\mathrm{Ni}$ & Mo & W & V & Co & $\mathrm{Cu}$ \\
\hline WCL & $0,32-0,42$ & $0,2-0,5$ & $0,8-1,2$ & $\begin{array}{c}\text { maks. } \\
0,03\end{array}$ & $\begin{array}{c}\text { maks. } \\
0,03\end{array}$ & $4,5-5,5$ & $\begin{array}{c}\text { maks. } \\
0,35\end{array}$ & $1,2-1,5$ & $\begin{array}{c}\text { maks. } \\
0,3\end{array}$ & $0,3-0,5$ & $\begin{array}{c}\text { maks. } \\
0,3\end{array}$ & $\begin{array}{c}\text { maks. } \\
0,3\end{array}$ \\
\hline
\end{tabular}




\section{Spoiwa do napawania}

Często jako jedno z głównych kryteriów doboru rodzaju spoiwa, oprócz składu chemicznego, brana jest pod uwage wymagana twardość napoiny. Takie założenie przyjęto też przy opracowywaniu technologii regeneracji formy trwałej ze stali WCL do odlewania zacisków hamulcowych ze stopu aluminium.

Do próby napawania kokili metodą TIG użyto dwóch rodzajów spoiw - 6500 WIG firmy Capilla oraz LNT NiCro 60/20 firmy LINCOLN.

Pręty 6500 WIG (DIN 8555: WSG 6-GZ-50 T) są przeznaczone przede wszystkim do napawania metodą TIG. Stosuje się je do naprawy form odlewniczych oraz innych narzędzi ze stali WCL lub innych gatunków stali narzędziowych do pracy na gorąco o zbliżonym składzie chemicznym. Stopiwo z tych prętów charakteryzuje się dobrą wytrzymałością i wysoką odpornością temperaturową do $500^{\circ} \mathrm{C}$. Skład chemiczny drutu przedstawiono $\mathrm{w}$ tablicy II.

Napoinę wykonaną spoiwem 6500 WIG można obrabiać cieplnie, uzyskując właściwości podobne do właściwości napawanej stali.

Zgodnie z zaleceniem producenta spoiwa, stal przed napawaniem wymaga podgrzania do $300 \div 500^{\circ} \mathrm{C}$ (maks. temperatura odpuszczania materiału podstawowego), natomiast stale niskostopowe powinny być podgrzane do $200 \div 300^{\circ} \mathrm{C}$. Chłodzenie po napawaniu powinno odbywać się powoli w piecu. Bezpośrednio po napawaniu stopiwo ma twardość $50 \div 55 \mathrm{HRC}$.

Pręty NiCro 60/20 są spoiwem austenitycznym, na bazie niklu, z dużą zawartością chromu, molibdenu i niobu, przeznaczonym głównie do spawania stopów niklu. Stosowane są z powodzeniem do spawania stali różniących się składem chemicznym oraz do zastosowań specjalnych wymagających odporności na korozję i wysoką temperaturę. Wykazują wysoką odporność na pękanie na gorąco, a także odporność na nawęglanie w wysokiej temperaturze (maks. $1200^{\circ} \mathrm{C}$ ). Skład chemiczny wg producenta podano w tablicy III, natomiast właściwości mechaniczne stopiwa w tablicy IV.

Próby napawania wykonano z zastosowaniem obu spoiw układając napoiny na płytach ze stali, WCL oraz na wkładce formy odlewniczej również wykonanej $z$ tej stali (rys. 3, 4). Wyniki analizy składu chemicznego napoin wykonanej na spektrometrze firmy LECO przedstawiono $w$ tablicy V.

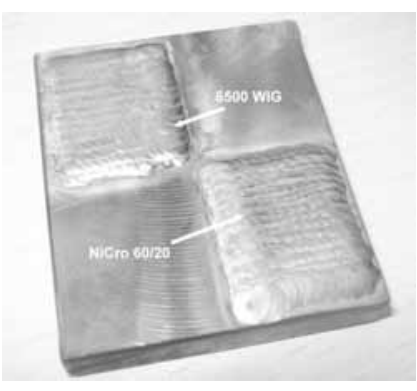

Rys. 3. Płyta ze stali WCL do technologii napawania

Fig. 3. WCL steel plate for surfacing by welding technology

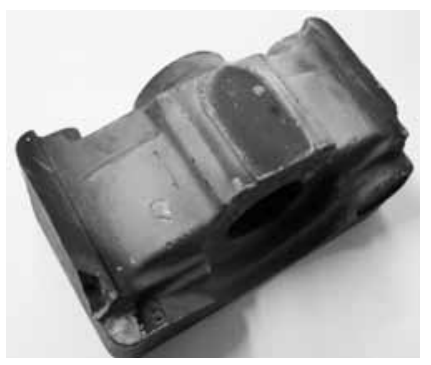

Rys. 4. Wkładka kokili wyjęta z formy przeznaczona do wykonania prób napawania Fig. 4. The mould insert for the surfacing by welding tests

Tablica II. Skład chemiczny drutu 6500 WIG [5]

Table II. Chemical composition of 6500 WIG wire [5]

\begin{tabular}{|c|c|c|c|c|c|c|}
\hline $\mathrm{C}$ & $\mathrm{Si}$ & $\mathrm{Mn}$ & $\mathrm{Cr}$ & $\mathrm{Mo}$ & $\mathrm{V}$ & $\mathrm{Fe}$ \\
\hline 0,4 & $0,8-1,2$ & $0,4-0,7$ & $5,0-7,0$ & $1,2-1,8$ & $0,8-1,2$ & reszta \\
\hline
\end{tabular}

Tablica III. Skład chemiczny drutu LNT NiCro 60/20 [6]

Table III. Chemical composition of LNT NiCro 60/20 wire [6]

\begin{tabular}{|c|c|c|c|c|c|c|c|c|c|c|c|c|}
\hline C & $\mathrm{Mn}$ & $\mathrm{Fe}$ & $\mathrm{P}$ & $S$ & $\mathrm{Si}$ & $\mathrm{Cu}$ & Al & $\mathrm{Ti}$ & $\mathrm{Ni}$ & \multirow{2}{*}{$\mathrm{Cr}$} & \multirow{2}{*}{$\mathrm{Nb}+\mathrm{Ta}$} & \multirow{2}{*}{ Mo } \\
\hline \multicolumn{9}{|c|}{ maks. } & $\min$. & & & \\
\hline 0,10 & 0,50 & 5,0 & 0,02 & 0,015 & 0,50 & 0,50 & 0,40 & 0,40 & 58,0 & $20,0-23,0$ & 3,5 & $8,0-10,0$ \\
\hline
\end{tabular}

Tablica IV. Właściwości mechaniczne stopiwa LNT NiCro 60/20 [6]

Table IV. Mechanical properties of LNT NiCro 60/20 weld metal [6]

\begin{tabular}{|c|c|c|c|c|}
\hline Granica plastyczności $\mathrm{R}_{0.2}, \mathrm{~N} / \mathrm{mm}^{2}$ & Wytrzymałość na rozciąganie $\mathrm{R}_{\mathrm{m}}, \mathrm{N} / \mathrm{mm}^{2}$ & \multirow{2}{*}{ Wydłużenie $\mathrm{A}_{5}, \%$} & \multicolumn{2}{|c|}{ Udarność ISO V, J } \\
\cline { 3 - 6 } & 815 & 38 & 182 & $196^{\circ} \mathrm{C}$ \\
\hline 540 & & 389 & 129 \\
\hline
\end{tabular}

Tablica V. Zawartość pierwiastków stopowych w napoinach

Table V. Alloying elements in padding welds

\begin{tabular}{|l|c|c|c|c|c|c|c|c|c|c|c|c|c|}
\hline Napoina & $\mathrm{C}$ & $\mathrm{Mn}$ & $\mathrm{Si}$ & $\mathrm{P}$ & $\mathrm{S}$ & $\mathrm{Cr}$ & $\mathrm{Ni}$ & $\mathrm{Mo}$ & $\mathrm{V}$ & $\mathrm{W}$ & $\mathrm{Cu}$ & $\mathrm{Co}$ & $\mathrm{Nb}$ \\
\hline NiCro 60/20 & 0,1 & 0,12 & 0,33 & 0,03 & 0,04 & 19,8 & $>42,9$ & $>1,67$ & 0,17 & 0,07 & 0,1 & 0,11 & $>0,77$ \\
\hline 6500 WIG & 0,38 & 0,34 & 1 & 0,02 & 0,004 & 5,14 & 0,14 & 1,21 & 0,43 & 0,12 & 0,34 & 0,07 & $\mathrm{Fe}$ reszta \\
\hline
\end{tabular}




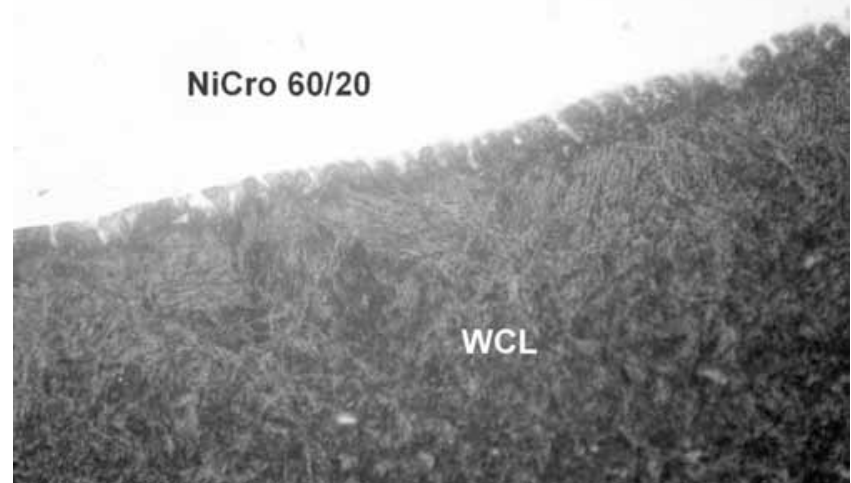

Rys. 5. Napoina NiCro $60 / 20$ na stali WCL. Pow. 500x. Trawiono Nitalem

Fig. 5. NiCro 60/20 padding weld on the WCL steel. Magn. 500x, Nital etching

Zawartości pierwiastków stopowych w napoinie NiCro 60/20 są orientacyjne, z uwagi na brak odpowiednio dokładnego wzorca do oznaczania składu chemicznego $z$ takiego materiału.

Podczas napawania stwierdzono, że stopiwo z drutu NiCro 60/20 dobrze zwilża powierzchnię materiału wkładki i na granicy napoiny ze stalą widać strefę przejściową charakterystyczną dla połączenia materiałów różniących się istotnie składem chemicznym (rys. 5).

\section{Technologia naprawy napawaniem form odlewniczych}

Przy wyborze rodzaju spoiwa należy wziąć pod uwage przede wszystkim warunki pracy formy odlewniczej. Należy przy tym uwzględnić także rodzaj obróbki ubytkowej potrzebnej do ukształtowania napawanej formy. Podczas wytwarzania nowej formy stosowana stal jest w stanie miękkim, łatwym do kształtowania wieloma rodzajami obróbki, natomiast przy regeneracji ma się do czynienia z formą w stanie twardym po ulepszaniu cieplnym i wówczas liczba sposobów obróbki ubytkowej możliwych do zastosowania jest mocno ograniczona, zależy bowiam m.in. od stopnia skomplikowania kształtu formy, miejsc położenia napoiny i wymaganej dokładności oraz jakości powierzchni obrabianej.

Przed napawaniem należy powierzchnie formy odpowiednio przygotować, usuwając uszkodzone miejsca aż do zdrowego materiału. Przy głębokich uszkodzeniach materiału formy, dużym zasięgu prac jej napawania i skomplikowanym kształcie formy wymagana jest dobra obrabialność skrawaniem. Wówczas właściwym zabiegiem przed regeneracją jest poddanie formy odlewniczej wyżarzaniu zmiękczającemu i zastosowanie zabiegów cieplnych związanych z napawaniem niedopuszczających do utwardzenia napoiny.

Wiele materiałów spawalniczych stosowanych do napawania pozwala jednak uzyskiwać napoiny o wymaganych właściwościach, jak np. odpowiednią twardości, bezpośrednio po napawaniu bez konieczności

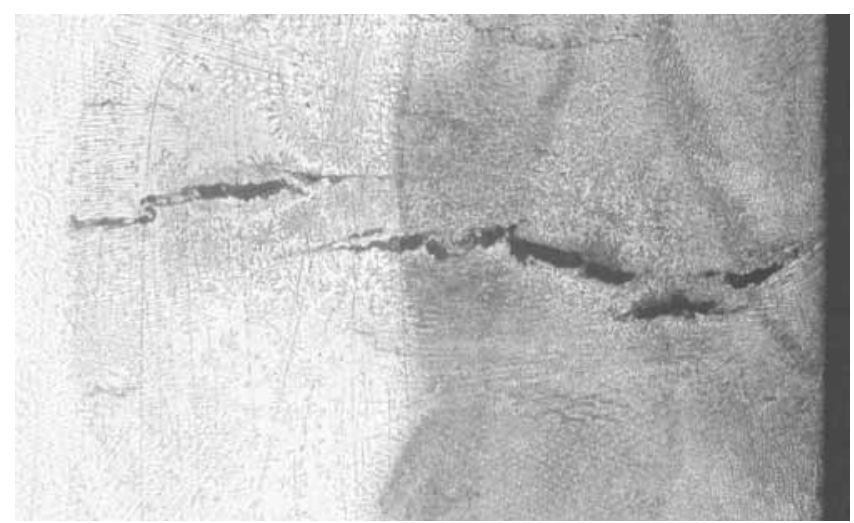

Rys. 6. Napoina 6500 WIG na stali WCL. Pow. 200x. Trawiono Nitalem

Fig. 6. 6500 WIG padding weld on the WCL steel. Magn. 200x. Nital etching

dodatkowej obróbki ulepszania cieplnego. Jeżeli napoiny nie poddaje się zmiękczeniu do kształtowania formy po napawaniu stosuje się obróbkę elektroerozyjną, która nie ma ograniczeń związanych z twardością materiału.

Powierzchnie napawane o prostych kształtach, jak np. płaskie powierzchnie przylgowe formy, obrabia się na ogół frezowaniem lub szlifowaniem. W przypadku omawianej formy do odlewania zacisków hamulcowych twardość napoin NiCro 60/20 wynosiła ok. $200 \mathrm{HB}$, natomiast twardość warstwy 6500 WIG bezpośrednio po napawaniu wyniosła ok. $52 \mathrm{HRC}$. Zatem powierzchnia ma odpowiednie właściwości użytkowe, a powierzchnie przylegania łatwo poddają się obróbce skrawaniem. Do ksztaltowania formy po napawaniu stosowano dwa rodzaje obróbki ubytkowej - obróbkę elektroerozyjną do gniazda formującego odlew oraz frezowanie do powierzchni podziałowych formy.

Jeżeli jednak cała kokila (powierzchnie przylgowe i gniazdo formujące) zostaną napawane jednym gatunkiem spoiwa 6500 WIG, to po napawaniu wymagane jest wyżarzanie zmiękczające $\left(750 \div 780^{\circ} \mathrm{C} / 2 \div 4 \mathrm{~h}\right)$, a po obróbce skrawaniem należy przeprowadzić ulepszanie cieplne (hartowanie z $1020 \div 1050^{\circ} \mathrm{C}$ w oleju z następnym odpuszczaniem w temp. $500 \div 550^{\circ} \mathrm{C}$ do uzyskania

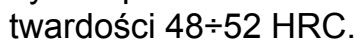

Spoiwo LNT NiCro 60/20 ma bardzo dobre właściwości technologiczne i łatwo się nim nakłada napoiny, ale z tym związane jest też pewne niebezpieczeństwo wynikające $z$ błędnego przekonania spawaczy o braku potrzeby podgrzewania wstępnego kokili ponieważ w napoinie nie widać pęknięć, oraz że po bezpośrednio po napawaniu brzegów kokila jest na tyle podgrzana, że można od razu przystąpić do dalszego napawania gniazda formującego. Jest to mylące, bowiem nieciągłości materiału nie muszą być widoczne lub występować na powierzchni napoiny. Jak wykazały badania metalograficzne napoin ze spoiwa 6500 WIG (które odpowiada składem chemicznym stali WCL), w niepodgrzanej dostatecznie wkładce formy (rys. 6) i przy braku kontroli temperatury międzyściegowej występują liczne nieciągłości materiału w postaci pęknięć, 
które nie wychodzą na powierzchnię napoiny. Ostre wierzchołki pęknięć mogą w czasie pracy kokili być powodem spiętrzenia naprężeń i uszkodzenia formy, co powoduje konieczność przeprowadzenia przedwczesnego procesu regeneracji elementu. Twardość warstwy 6500-WIG bezpośrednio po napawaniu wyniosła ok. 52 HRC.

Zachowanie odpowiednich warunków cieplnych związanych z napawaniem regeneracyjnym kokili pozwoliło na uzyskanie struktury materiału bez takich wad, nawet jeśli proces regeneracji nie przewidywał ponownej obróbki cieplnej po napawaniu właściwej dla stali WCL.

\section{Zalecenia technologii napawania kokili}

Opracowana technologia dotyczy regeneracji $100 \%$ gniazda formującego oraz krawędzi przylegania części kokili. Przed regeneracją kokilę należy poddać dokładnemu czyszczeniu mechanicznemu i chemicznemu, a następnie na współrzędnościowej maszynie pomiarowej określić wielkości zużycia na poszczególnych powierzchniach formy. W większości przypadków ubytki materiału kokili wynoszą $0,1 \div 0,3 \mathrm{~mm}$, a tylko miejscowo występują większe wartości $0,5 \div 1,0 \mathrm{~mm}$. Niewielkie zużycie kokili wymaga napawania warstw o niewielkiej grubości, co znacznie ułatwia proces regeneracji.

Napawanie należy rozpocząć od zabezpieczenia brzegu formy. Do tego celu dobrze nadaje się cienkie spoiwo LNT NiCro 60/20 o średnicy $0,8 \mathrm{~mm}$ napawane przy małym natężeniu prądu, tak aby nadmiernie nie przetopić krawędzi (np. dla średnicy drutu 0,8 mm, średnicy elektrody WT20 1,6 mm, natężenie prądu wynosiło ok. 40 A). Napawanie powierzchni

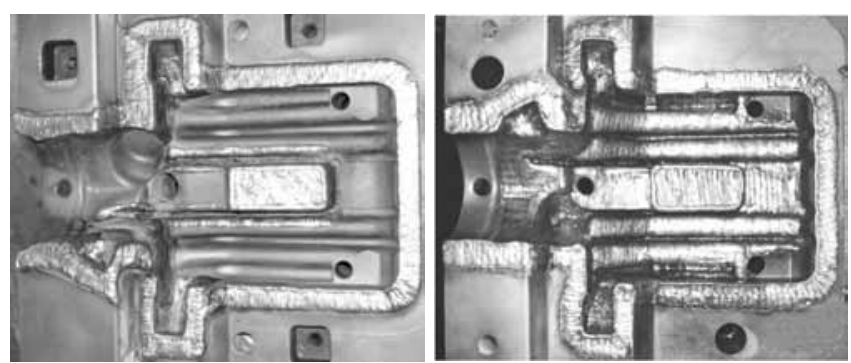

Rys. 7. Formy odlewnicze o różnym stopniu zużycia z lokalnie napawanymi powierzchniami formującymi spoiwem 6500 WIG i powierzchniami przylegania spoiwem NiCro 60/20

Fig. 7. Varying degree of surfaces wear of casting forms with locally 6500 WIG surfacing by welding of mould and NiCro 60/20 surfacing of contact surfaces

dalej położonych od brzegu kokili wygodniej jest wykonać z użyciem grubszego spoiwa, odpowiednio zwiększając przy tym prąd spawania (np. dla drutu 1,6 mm $I_{\text {sp }}$ przyjąć ok. 90 A). Spoiwo LNT NiCro 60/20 ma bardzo dobre właściwości technologiczne i łatwo się nim nakłada nakłada napoiny, lecz należy pamiętać o warunkach cieplnych podgrzewania wstępnego kokili. Opinia, że po napawaniu powierzchni przylegania kokila jest dostatecznie dogrzana i można przystąpić do napawania gniazda formującego jest błędna. Badania metalograficzne wykazały, że pęknięcia często występują wewnątrz napoiny i w badaniach wizualnych mogą pozostać niewykryte (rys. 5).

Do napawania gniazda zaleca się wybór drutu 6500 WIG. Napawanie gniazda należy rozpocząć od miejsc o trudnym dostępie bądź trudnych technicznie (żebra, głębokie wnęki, przewężenia), dobierając odpowiednio średnicę drutu.

Przykłady napawanych kokili o różnym stopniu zużycia pokazano na rysunku 7.

\section{Podsumowanie}

Zastosowane materiały spawalnicze do napawania pozwalają na stosunkowo szybką i uproszczoną technologicznie regenerację zużytych kokili do zacisków hamulcowych odlewanych ze stopu AISi. Przed napawaniem należy starannie przygotować powierzchnie formy odlewniczej. Zaleca się bezwzględnie przestrzegać odpowiednich warunków cieplnych związanych z procesem regeneracji celem uniknięcia pęknięć w napoinach.

Metoda TIG dobrze nadaje się do napawania elementów formy odlewniczej. Zastosowanie cienkich spoiw o średnicy $0,8 \div 1,2 \mathrm{~mm}$ umożliwia łatwe układanie napoin na krawędziach bez ich nadmiernego przetopu. Do napawania większych powierzchni formy odlewniczej zaleca się użyć grubszych spoiw o średnicy $1,2 \div 2,0 \mathrm{~mm}$. W porównaniu do napawania laserowego proszkami metoda TIG jest wielokrotnie bardziej ekonomiczna, a trwałość regenerowanych kokili jest zbliżona.

Zastosowanie dwóch rodzajów spoiw do napawania różnych części formy odlewniczej wymaga zastosowania obróbki erozyjnej do kształtowania powierzchni formującej kokili, natomiast powierzchnie przylgowe mogą być obrabiane skrawaniem. 


\section{Literatura}

[1] Białecki M. Charakterystyki stali. Stale narzędziowe. Wyd. Śląsk, Katowice.

[2] Dobrzański L.A.: Podstawy nauki o materiałach i materiałoznawstwo, Gliwice 2002.

[3] Pilarczyk J. (red). Poradnik inżyniera. Spawalnictwo. T.1. WNT, Warszawa 2003r.

[4] Pilarczyk J. (red.). Poradnik inżyniera. Spawalnictwo. T.2 WNT, Warszawa 2005r.
[5] MAG/WIG, TIG drôty pre navarovanie ocelí pre prácu za tepla - Mat. Inf. f-my Technomat, http://www.technomat.sk/eshop/ action/productdetail/oc/518/product/capilla-4914-mag-wig. xhtml 15-06-2011.

[6] The Lincoln Electric Company, Nickel-Based Alloy Mig Wire And Tig Cut Lengths, LNM NiCro 60/20, LNT NiCro 60/20.Mat. inf. http://content.lincolnelectric.com/pdfs/products/ literature/ c6101.pdf. 15-06-2011.

\section{Międzynarodowa Konferencja Naukowo-Techniczna \\ NAPAWANIE - POSTąP I ZASTOSOWANIA \\ Wroclaw, 19-21 wrzesień 2011}

\section{SESJA IV Właściwości powłok}

\begin{tabular}{|c|c|c|c|}
\hline \multicolumn{4}{|c|}{ Środa, 21.09.2011 } \\
\hline \multicolumn{4}{|c|}{ Przewodniczący: prof. dr hab. inż. Jerzy Łabanowski, dr inż. Hubert Drzeniek } \\
\hline Godzina & Część & Autorzy & Tytuł \\
\hline $9^{00}$ & A & $\begin{array}{l}\text { Dr hab. inż. Igor Riabcev } \\
\text { Instytut Spawalnictwa, } \\
\text { im. E.O. Patona, Kijów, Ukraina }\end{array}$ & $\begin{array}{l}\text { Структурная наследственность в } \\
\text { наплавочных процесcax (,Strukturalna } \\
\text { dziedziczność w procesach napawania”) }\end{array}$ \\
\hline $9^{20}$ & A & $\begin{array}{l}\text { Prof. dr hab. inż. Jerzy Nowacki } \\
\text { ZUT Szczecin } \\
\text { Mgr inż. Artur Wypych } \\
\text { Politechnika Poznańska }\end{array}$ & $\begin{array}{l}\text { Napawanie w regeneracji głowic } \\
\text { cylindrowych silników okrętowych }\end{array}$ \\
\hline $9^{40}$ & A & $\begin{array}{l}\text { Prof. dr hab. inż. Andrzej Gruszczyk } \\
\text { Politechnika Śląska, Gliwice }\end{array}$ & $\begin{array}{l}\text { Kształtowanie struktury napoin żeliwnych przez } \\
\text { podwyższenie ich zdolności go grafityzacji }\end{array}$ \\
\hline $10^{00}$ & A & $\begin{array}{l}\text { Dr inż. Jerzy Niagaj } \\
\text { Instytut Spawalnictwa, Gliwice }\end{array}$ & $\begin{array}{l}\text { Wpływ niobu na właściwości warstw } \\
\text { wierzchnich napawanych samoosłonowymi } \\
\text { drutami proszkowymi o stopiwie Fe-Cr-C }\end{array}$ \\
\hline \multicolumn{4}{|c|}{ PRZERWA NA KAWE } \\
\hline \multicolumn{4}{|c|}{ Przewodniczący prof. dr hab. inż. Andrzej Gruszczyk, dr hab. inż. Andrzej Ambroziak prof. PWr } \\
\hline $10^{40}$ & B & $\begin{array}{l}\text { dr hab. inż. Tadeusz Hejwowski prof. PL } \\
\text { Dr Jakub Nowak } \\
\text { Mgr inż. Tomasz Nastaj } \\
\text { Politechnika Lubelska }\end{array}$ & $\begin{array}{l}\text { Mikrostruktura i odporność na zużycie } \\
\text { powłok napawanych plazmowo stopami } \\
\text { na osnowie niklu i kobaltu }\end{array}$ \\
\hline $11^{100}$ & B & $\begin{array}{l}\text { Dr inż. Jerzy Gołąbek } \\
\text { Welding Alloys Polska }\end{array}$ & $\begin{array}{l}\text { Zużycie ścierne } w \text { procesie rozdrabniania } \\
\text { minerałów }\end{array}$ \\
\hline $11^{20}$ & B & $\begin{array}{l}\text { Mgr inż. Tomasz Mucha, Konrad Bartkowiak } \\
\text { KWB Turów }\end{array}$ & $\begin{array}{l}\text { Zastosowanie napawanych płyt } \\
\text { trudnościeralnych w naprawach } \\
\text { maszyn podstawowych górnictwa } \\
\text { odkrywkowego }\end{array}$ \\
\hline $11^{40}$ & \multicolumn{3}{|c|}{ PODSUMOWANIE I ZAKOŃCZENIE KONFERENCJI } \\
\hline $12^{10}$ & \multicolumn{3}{|c|}{ OBIAD } \\
\hline
\end{tabular}

